ISSN: 2528-9527

E-ISSN: 2528-9535

YIl Year: 9

Cilt Volume: 11

Sayı Issue: 18

\title{
Suriyeli Sığınmacıların Türkiye'ye Göç Sonrası Yaşadığı Sorunlar: İstanbul Örneği ${ }^{1}$
}

\author{
DOI: $10.26466 /$ opus.558512
}

\section{Güler Güneș Aslan* - Fethi Güngör**}

* Arş. Gör. Dr., Yalova Üniversitesi İktisadi ve İdari Bilimler Fakültesi, Merkez/ Yalova/ Türkiye E-Posta: guler.gunes@yalova.edu.tr ORCID: $\quad$ 0000-0002-6509-8278

** Doç. Dr., Yalova Üniversitesi İktisadi ve İdari Bilimler Fakültesi, Merkez/ Yalova/ Türkiye E-Posta: fethi.gungor@yalova.edu.tr ORCID: $\underline{0000-0003-2581-0205}$

\section{Öz}

Sığınma amaçlı göç 21. yüzyılı şekillendiren önemli toplumsal olaylardan biridir. Savaş, iç çatışmalar, siyasi çekişmeler, kamu otoritesinin uyguladığı ayrımcılık gibi sebeplerle insan toplulukları farklı ülkelere göç etmektedir. Türkiye çeşitli ülke ve örgütlerin dahil olduğu savaş ortamından kaçan milyonlarca Suriyeli sı̆̆ınmacıya ev sahipliği yapan ülkelerin başında gelmektedir. 2018 sonu itibarıyla Türkiye'nin hemen her şehrinde Suriyeli sığınmacı bulunmaktadır. Bu çalışmada İstanbul'da yaşayan Suriyeli sığınmacıların göç sonrasında yaşadıkları sorunlar incelenmiştir. 76 Suriyeli sığınmacı ile Türkçe, Arapça ve Kürtçe bilen tercüman eşliğinde derinlemesine mülakatlar yapılmıştır. Mülakatlardan elde edilen veriler MAXQDA 2018 nitel veri analizi programıla analiz edilip temalara ayrulmıştır. Böylece Suriyeli sı̆̆ı̆mactların İstanbul'da yaşarken deneyimledikleri ve kendi objektiflerinden sorun olarak gördükleri olguları yansıtmaları sağlanmıştır. Alanda derlenen verilerden yola çıkarak belirlenen; ülkenin dilini bilmemek, resmî işlemlerde engellerle karşılaşmak, iş piyasasından ve toplumdan dışlanmak, geçinme, barınma, sağllk, eğitim ve uyum sorunları yaşamak, sosyal hizmet ve sosyal destek alamamak gibi sorun temalarına bulgular ve tartışma kısmında yer verilmiştir. Sorunlarla ilgili çözüm önerileri ise sonuç bölümünde sıralanmıştır.

Anahtar Kelimeler: Göç, Mülteci, Suriyeli Sığınmacı, Sığınmacıların Sorunları.

\footnotetext{
1 Bu çalışma, Yalova Üniversitesi Bilimsel Araştırma Projeleri Komisyonu tarafından desteklenen 2015/D/062 numaralı doktora tezinden üretilmiştir.
} 


\title{
The Problems of Syrian Refugees Faced After Migration to Turkey: Case of Istanbul
}

\begin{abstract}
Asylum-seeking migration is one of the important social events that shapes the $21^{\text {st }}$ century. Human societies migrate to different countries due to war, internal conflicts, political conflicts and discrimination by public authority. Millions of Syrian refugees that fled from the battlefield environment involving various countries and organizations are housed in Turkey. Turkey has Syrian refugees in almost every city. In this study, the problems of Syrian refugees living in Istanbul were examined. In-depth interviews were conducted with 76 Syrian refugees by researcher accompanied by a translator who knows Turkish, Arabic and Kurdish. The data obtained from the interviews were analyzed by using the MAXQDA 2018 qualitative data analysis program. Based on the data obtained from the interviews, the determined themes of the problem such as not knowing the language of the country, encountering obstacles in the official procedures, living, sheltering, health, education and adaptation issues are given in the findings and discussion section. Suggestions about the problems are given in the conclusion section.
\end{abstract}

Keywords: Migration, Refugee, Syrian Asylum Seeker, Asylum Seeker's Problems. 


\section{Giriş}

Suriyeli sığınmacılar Türkiye Cumhuriyeti'nin gerek siyasi gerekse toplumsal gündeminde sıklıkla yer almaktadır. Suriyeli sığınmacılar Türkiye'ye gelmeye başladığından beri Türkiye'ye kabulleri tartışma konusu olmuştur. Kimi siyasiler Suriyelilerin Türkiye'ye iltica etmesine şiddetle karşı çıkarken, kimileri de çatışma ve savaş bölgesinden kaçan bu grubun Türkiye'ye yerleştirilmesini desteklemiştir. Türk toplumunda da Suriyelilerin varlığ sıcak bir tartışma konusudur. Kimi toplum kesimleri Suriyelilerin Türkiye'deki varlığına destek verirken, kimi kesimler bundan rahatsız olmaktadır. Suriyelilerin Türkiye'ye ilk geldiği 2011 yılından itibaren Türkiye Cumhuriyeti açık kapı politikası uygulamış ve Türkiye'ye gelen Suriyeli sığınmacı sayısı ilk dönemde yüksek bir hızla artmıştır. Türkiye Cumhuriyeti'nin 'açık kapı' politikasını terk etmesinden sonra Suriyeliler Türkiye'ye kaçak yolla ya da vizeyle girmeye başlamıştır. Nihayetinde 2011-2018 yılları arasında Türkiye'de hatırı sayılır bir Suriyeli nüfusu oluşmuştur. Birleşmiş Milletler Mülteciler Yüksek Komiserliği (BMMYK)'nin 19.04.2019 tarihine ait verilerine göre Türkiye'de 3.621.330 Suriyeli sığınmacı bulunmaktadır. Dünyada kayıtlı 5.648.002 Suriyeli sığınmacı bulunurken, Türkiye dünyada en fazla Suriyeli sığınmacı barındıran ülkedir. Türkiye'yi sırayla Lübnan, Ürdün, Irak ve Mısır takip etmektedir (BMMYK, 2019). Bu sayı Türkiye Cumhuriyeti için önemli bir sayıdır. Suriyelilerin bulundukları şehirlerdeki yoğunlukları kimi zaman yerel halkın sayısını aşmış, Suriyelilerin yerleşimi önemli bir toplumsal mesele haline gelmiştir. Günlük hayattaki söylemlerde ve sosyal medyada Suriyelilerle ilgili ekonomik ve sosyal meseleler sıklıkla tartışılmaktadır.

Konu ile ilgili kavrayışı genel düzeyden özel düzeye götürmek için şartlı mülteci/sığınmacı ve mülteci kavramlarına yer verilmiştir. İlgili kavramları anlayabilmek için öncelikle hukuki çerçeveden bakmak gerekmektedir.

Türkiye Büyük Millet Meclisi'nde 04.04.2013 tarihinde kabul edilen, 11.04.2013'te Resmî Gazete'de yayınlanan 6458 sayılı Yabancilar ve Uluslararası Koruma Kanunu'nun 61. ve 62. Maddelerinde Avrupa ülkelerinden gelen zorunlu göçmenleri mülteci, Avrupa ülkeleri dışından Türkiye'ye gelen zorunlu göçmenleri şartlı mülteci olarak tanımlanmıştır. 
- MADDE 61 - (1) Avrupa ülkelerinde meydana gelen olaylar nedeniyle; 1rk1, dini, tabiiyeti, belli bir toplumsal gruba mensubiyeti veya siyasi düşüncelerinden dolayı zulme uğrayacağından haklı sebeplerle korktuğu için vatandaşı olduğu ülkenin dışında bulunan ve bu ülkenin korumasından yararlanamayan ya da söz konusu korku nedeniyle yararlanmak istemeyen yabanciya veya bu tür olaylar sonucu önceden yaşadığı ikamet ülkesinin dışında bulunan, oraya dönemeyen veya söz konusu korku nedeniyle dönmek istemeyen vatansız kişiye statü belirleme işlemleri sonrasında mülteci statüsü verilir.

- MADDE 62 - (1) Avrupa ülkeleri dişında meydana gelen olaylar sebebiyle; 1rk1, dini, tabiiyeti, belli bir toplumsal gruba mensubiyeti veya siyasi düşüncelerinden dolayı zulme uğrayacağından haklı sebeplerle korktuğu için vatandaşı olduğu ülkenin dişında bulunan ve bu ülkenin korumasından yararlanamayan ya da söz konusu korku nedeniyle yararlanmak istemeyen yabanciya veya bu tür olaylar sonucu önceden yaşadığı ikamet ülkesinin dişında bulunan, oraya dönemeyen veya söz konusu korku nedeniyle dönmek istemeyen vatansız kişiye statü belirleme işlemleri sonrasında şartlı mülteci statüsü verilir. Üçüncü ülkeye yerleştirilinceye kadar, şartlı mültecinin Türkiye'de kalmasına izin verilir (Resmî Gazete, 2013).

Türkiye Avrupa ülkeleri dışından gelen zorunlu göçmenleri mülteci olma şartlarını taşısalar dahi mülteci statüsü vermemekte, üçüncü ülkeye yerleşene kadar Türkiye'ye sığınma hakkı vermektedir. Bu bağlamda şartlı mültecilere Türkiye'de sığınmacı da denmektedir.

Türkiye Cumhuriyeti'ne sığınan Suriyeliler Türkiye'ye yoğun bir göç dalgası ile gelmeleri sebebiyle kendileri için geçici koruma statüsü oluşturulmuştur. Geçici koruma statüsü kitlesel göç durumlarında standart sığınmacı değerlendirme prosedürlerinin uygulanmaması için oluşturulmuştur. Türkiye Cumhuriyeti, Suriyelileri açık kapı politikası ile ülke topraklarına kabul edip geri göndermeme ilkesine uygun davranmıştır. İlaveten Türkiye topraklarına göç eden Suriyelilerin acil ve temel ihtiyaçlarını karşılayarak Suriyelilere geçici koruma sağlamıştır (T.C. İçişleri Bakanlığ1 Göç İdaresi Genel Müdürlüğü, 2015). 
Geçici koruma altındaki Suriyeliler, mülteci olabilme şartları taşısalar da Türkiye Cumhuriyeti'nin koyduğu bölge kısitlamasına göre Türkiye'de mülteci statüsü alamayacaklardır. Bunun yerine sığınmacı ya da şartlı mülteci tanımını alacaklardır. Bu çalışmada Suriyeliler sığınmacı olarak ele alınmıştır.

Suriyeli sığınmacıların gerçekleştirdiği göç, Petersen'in 'göçmenin sosyal bağlamın etkisi altında inisiyatif alamadan göç etmek durumu' olarak tanımladığı zorunlu göç (Akt. Çağlayan, 2006, s.75-76) olarak değerlendirilebilir. Sığınmacıların hareketliliğini tanımlayan zorunlu göçü Castells ve Miller modernleşme ve küreselleşmenin semptomu olarak görür. Göç-sığınma bağı düşüncesine göre sömürgecilik, sanayileşme, dünya ekonomisindeki değişimler, geleneksel üretim biçimlerini ve sosyal ilişkileri tahrip ederken ulusları ve devletleri dönüştürmüştür. Azgelişmişlik, yoksullaşma, iktidarların kötü yönetimi ve yaptıkları insan hakları ihlalleri, iç çatışmalar birbirleriyle bağlantılı olarak ekonomik temelli veya siyasi sebeple göçlere neden olurlar (Castells ve Miller, 2008, s.44).

Altta yatan sorunsallarıyla çoğu zaman hazırlıksız olarak gerçekleşen zorunlu göç insanların bulunduğu coğrafyadan, psikososyal ve ekonomik sistemlerden kopup başka coğrafya ve sistemlere adapte olmasını gerektiren bir meseledir. Birey ve insan topluluklarını baş etmeleri için birçok problemle karşılaştıran bir süreçtir. Bu çalışmada Suriyeli sığınmacıların Türkiye'ye zorunlu göçleri sonrası yaşadıkları problemler İstanbul örneğinde ele alınmıştır.

\section{Araştırmanın Problemi}

Göç insanların ait olduğu sistemlerden kopmasına ve alışıldık olmayan yeni sistemlerle etkileşime girmesine neden olmaktadır. Bu etkileşim çok boyutlu olduğu için göçmenin aynı anda karşılaşacağı çeşitli sorunları beraberinde getirmektedir. Bu anlamda göçmen karmaşık bir sorun ağ1nın ortasında kalmaktadır. Bu çalışmanın ele aldığı problem İstanbul'daki Suriyeli sığınmacıların göç sonrası yaşadıkları sorunlardır. Bu çalışmada Suriyeli sığınmacıların İstanbul'da yaşarken deneyimledikleri, kendi objektiflerinden sorun olarak gördükleri olguları yansıtmaları sağlanmıştır. 


\section{Yöntem}

$\mathrm{Bu}$ çalışma nitel yöntemle gerçekleştirilmiştir. Bu bağlamda İstanbul'da yaşayan Suriyelilerin göç sonrası yaşadıkları problemleri öğrenmek için yarı yapılandırılmış mülakat tekniği kullanılmıştır. Çalışmaya ilk başlandığında bazı Suriyelilerin evleri ziyaret edilerek pilot görüşme yapılmıştır. Bu ziyaretlerde yapılan gözlem ve görüşmelerden hareketle yarı yapılandırılmış soru formu oluşturulmuştur.

Araştırma İstanbul'da bulunan Suriye Nur Derneği ve Şam Alimleri Vakfi'nda, Türkçe, Arapça ve Kürtçe bilen Suriyeli bir tercüman eşliğinde gerçekleştirilmiştir. Katılımcı Suriyelilere İstanbul'da Suriyeliler tarafından kurulmuş Suriye Nur Derneği ve Şam Alimleri Vakfı aracılığıyla ulaşılmasının sebebi, yabancı bir ülkede olmaktan dolayı tanımadıkları biriyle görüşürken yaşayacakları güven sorununu aşmaktır. Nitekim çalışmaya başlandığında araştırmaya katılma konusunda bilgilendirilip teklif götürülen çoğu Suriyeliden ret cevabı alınmıştır. Ancak ilgili sivil toplum kuruluşunda çalışan diğer Suriyeli çalışanların, katılımcılara ön bilgilendirme yapmasıyla gönüllülerin çalışmaya katılımı sağlanmıştır. Araştırma sürecinde 76 Suriyeli katılımcıyla görüşülmüştür. Görüşme sürecinde İstanbul'un çeşitli semtlerinden, çocuk, ergen, yetişkin ve yaşlı katılımcıların çalışmaya katılımı sağlanmıştır. Çalışma fenomenolojik yaklaşımla gerçekleştirilip, katılımcı Suriyelilerin göç sonrası yaşadıkları deneyimlere ait sorunları kendi pencerelerinden aktarmaları sağlanmıştır. Katılımcı Suriyelilerle yapılan mülakatlar yazıya geçirildikten sonra tematik analize tabi tutulmuştur. Veriler tekrar tekrar okunarak kodlanmış, çeşitli tema ve alt temalara ayrılmıştır. Analiz yaparken MAXQDA programı kullanılmıştır.

\section{Bulgular}

Çalışmanın bu kısmında katılımcıların cinsiyeti, yaş dağılımı, Türkçe bilme durumu ve Türkiye'ye ne zaman geldikleri ile ilgili verilere yer verilmiştir.

Bunun sonrasında Suriyeli sığınmacılarla yapılan mülakatların analiz edilmesiyle belirlenen sorunlara ait temalar incelenmiştir.

Tablo 1'de katılımclların cinsiyetine ait verilere yer verilmiştir. 
Tablo 1. Katılımcıların Cinsiyete Göre Dağılımı

Kadın 52

Erkek

24

Tablo 1'de gösterildiği gibi çalışmaya katılan katılımcıların 52'si kadın 24 'ü erkektir. Tablo 2'de katılımcıların yaş dağılımına ait verilere yer verilmiştir.

Tablo 2. Katılımcıların Yaş Dağılımı

\begin{tabular}{ll}
\hline Yaş aralı̆̆1 & $\mathrm{n}$ \\
\hline $12-18$ yaş & 4 \\
$19-29$ yaş & 21 \\
$30-39$ yaş & 20 \\
$40-49$ yaş & 10 \\
$50-59$ yaş & 14 \\
$60-64$ yaş & 3 \\
65 yaş üstü & 2 \\
\hline
\end{tabular}

74 kişiden alınan cevaba göre 4 kişi 12-18 yaş arasında, 21 kişi 19-29 yaş arasında, 20 kişi 30-39 yaş arasında, 10 kişi 40-49 yaş arasında, 14 kişi 5059 yaş arasında, 3 kişi 60-64 yaş arasında 2 kişi ise 65 yaşın üstündedir. Katılımcların yaş aralığı çeşitlilik göstermektedir. Tablo 3 'te ise katılımcıların Türkçe bilme durumuna ait verilere yer verilmiştir.

Tablo 3. Katılımcıların Türkçe Bilme Durumu

\begin{tabular}{ll}
\hline Türkçe bilme durumu & n \\
\hline Biliyor & 11 \\
Biraz Biliyor & 23 \\
Bilmiyor & 42 \\
\hline
\end{tabular}

11 kişi Türkçe bilmekte, 23 kişi biraz Türkçe bilmekte, 42 kişi Türkçe bilmemektedir. Buna göre katılımcıların çoğunluğu Türkçe bilmemektedir. Bu açıdan tercüman sürekli olarak görüşmelere katılmıştır. Tercümanın Suriyeli olması bunun yanında Türkçe, Arapça ve Kürtçe bilmesi görüşmeler açısından kolaylaştırıcı olmuştur. 
Tablo 4. Katılımcıların Türkiye'ye Ne Zaman Geldiğiyle İlgili Veriler

\begin{tabular}{ll}
\hline Süre & n \\
\hline 1 yıldan az & 7 \\
1 yıl önce & 8 \\
2 yil önce & 26 \\
3 yıl önce & 17 \\
4 yil önce & 12 \\
5 yıl önce & 6 \\
\hline
\end{tabular}

Katılımcılardan alınan cevaplara göre; 6 kişi 5 yıl, 1 kişi 4,5 yıl, 11 kişi 4 y1l, 3 kişi 3,5 yıl, 1 kişi 3 yıl 3 ay, 13 kişi 3 yıl, 5 kişi 2,5 yıl, 1 kişi 2 yıl 8 ay, 20 kişi 2 yıl, 4 kişi 1,5 yıl, 3 kişi 1 yıl, 1 kişi 1 yıl 1 ay, 7 kişi 1 yıldan az bir süre önce gelmiştir. Katılımcıların çoğunluğu Türkiye'ye ortalama 2-3 yıl önce gelmiştir.

Suriyeli sığınmacılarla yapılan mülakatlar sonrasında sorun alanları temaları ayırılarak, temalara ait yüzdeliklerle beraber Tablo 5'te gösterilmiştir.

Tablo 5. Suriyelilerin Göç Sonrası Yaşadığı Sorunlara Ait Temalar ve Yüzdelikleri

\begin{tabular}{|c|c|c|c|c|c|}
\hline Tema & $\mathbf{n}$ & $\%$ & Tema & $\mathbf{n}$ & $\%$ \\
\hline Dil Sorunu & 22 & 29 & Sağlık Sorunları & 16 & 21 \\
\hline $\begin{array}{l}\text { Resmî İşlerdeki } \\
\text { Sorunlar }\end{array}$ & 16 & 21 & $\begin{array}{l}\text { Sağlık Hizmetlerine } \\
\text { Erişim Sorunu }\end{array}$ & 7 & 9 \\
\hline $\begin{array}{l}\text { Kimlik Belgesi } \\
\text { Sorunu }\end{array}$ & 14 & 18 & Barınma Sorunları & 25 & 33 \\
\hline $\begin{array}{l}\text { Resmî Belgelerdeki } \\
\text { Eksiklikler }\end{array}$ & 8 & 11 & Ev İçi Sorunlar & 12 & 16 \\
\hline Maddi Sorunlar & 52 & 68 & Eğitim Sorunları & 11 & 14 \\
\hline İş Piyasasından Dışlanma & 35 & 46 & Çalıştırılan Çocuklar & 7 & 9 \\
\hline $\begin{array}{l}\text { Toplumdan Gelen Kötü } \\
\text { Davranışlar }\end{array}$ & 14 & 18 & $\begin{array}{l}\text { Türkiye'ye Alışma ve Uyum Sağlama } \\
\text { Konusundaki Sorunlar }\end{array}$ & 23 & 30 \\
\hline Toplumdan Dişlanma & 22 & 29 & Sosyal Destek Almamak & 14 & 18 \\
\hline $\begin{array}{l}\text { Psikososyal } \\
\text { Sorunlar }\end{array}$ & 58 & 76 & $\begin{array}{l}\text { Sosyal Destek ve Sosyal Hizmet } \\
\text { Hakkında Bilgi Eksikliği }\end{array}$ & 8 & 11 \\
\hline
\end{tabular}

Tablo 5'te kaç kişi tarafından dile getirildiği ve dile getirilme sıklı̆̆1 gösterilen sorun temalarından sırasıyla bahsedilecektir. Maddi sorunlar, iş piyasasından dışlanma, psikososyal sorunlar gibi temalar metin içinde alt temalarıyla yer almıştır.

Katılımcıların en yaygın olarak dile getirdiği sorunlardan birisi dil sorunudur. Türkçe bilmemek önemli bir sorun olarak dile getirilmiştir. 
Hastaneye ve resmî dairelere giderken dil yüzünden sorun yaşamak, kimi zaman tercüman götürmek zorunda kalmak sıkça ifade edilen bir sorundur. Bazı katılımcılar karşılaştıkları tercümanların ihtiyaçlarını karşılamadığından bahsetmektedir. Bu durum özellikle sağlık hizmetlerinde sorun olmaktadır.

Katılımcıların \%21'i resmî işlerini hallederken sorun yaşadıklarını belirtmiştir. Bu sorunların uygulamadaki karmaşadan kaynaklandığını belirten katılımcılar bulunmaktadır. Kimi zaman bazı belgeleri vermek için birbirinden farklı belgelerin istenmesi kimi zaman da kimlik bilgilerinin kayıtlanmasındaki yanlışlıklar Suriyelilerin resmî dairelerdeki işlerini zorlaştırmaktadır. Bazı katılımcılar da uygulamada kararların sıklıkla değiştiğini beyan etmiştir. Örneğin:

M58: İstanbul Fatih'te uygulama ayrl, Esenyurt'a ya da Beylikdüzü'ne ya da başka bir ilçeye gidiyoruz, Suriyelilerle ilgili bir bilgi yok, ellerinde bir doküman yok. Mesela, gidiyorlar, herhangi bir resmî dairede işleri var, ev kirası akdi ya da doğalgaz, elektrik, su açtıracak. Bazen kimliği olanlarınki hemen yapılıyor. Kimi yerde kimlik de yeterli değ il, ikamet istiyorlar, açmıyorlar. Bu nasıl bir şey; bir ilçede yapılıyor, bir ilçede yapılmıyor, kişinin insafına kalmış. Böyle bir uygulama var.

Katılımcıların \%18'i kimlik belgesi edinmekte zorluk yaşadıklarını beyan etmiştir. Bazı katılımcıların kimlik belgesi bulunmamaktadır. Bazıları kendilerine verilen eski kimlik belgelerini yenileriyle değiştirmekte zorlanmaktadır. Farklı şehirden İstanbul'a göç eden bazı katılımcılar kayıtlarını İstanbul'a alarak kimlik belgesi çıkarmakta zorlanmaktadır. Bazı katılımcılar da kimlik belgesi çıarmanın oldukça zahmetli olduğunu beyan etmektedir. Kimlik belgesi meselesi önemli bir meseledir. Çünkü bu belgeye sahip olmayanlar resmî dairelerde işlerini halledememekte ve sağlık hizmetlerinden faydalanamamaktadır.

M1: Benim çocuğum doğarken annesinin kimliği yoktu. Elimizdeki belgeyi kabul etmediler. Belgeyi kabul etmedikleri için başka bir annenin kimliğini kullandık. Şimdi kimlikte başka birisi çocuğun annesi olarak yazıyor ama gerçekte çocuğun annesi eşim. Beyazıt'a gittiğimizde her şey karıştı. Bu bebeği kaçırdı$\breve{g}$ ımızı sandılar.

Katılımcların \%11'i Suriye'den diploma, evlilik cüzdanı gibi resmî belgeleri getirememiştir. Bu açıdan İstanbul'da evli olduklarını ya da eğitimli olduklarını ispatlayamamaktadırlar. 
Katılımcıların dile getirdiği en önemli sorunlardan biri maddi sorunlardır. Katılımcıların \%68'i maddi sorunlar yaşadığını dile getirmiştir. Tüm katılımcıların \%20'si ev kirasını önemli bir sorun olarak dile getirirken \%13'ü temel ihtiyaçlarını karşılamakta zorlandığını, \%58'i maddi yardıma ulaşamadığını, \%12'si de İstanbul'daki hayat pahalılığını dile getirmiştir.

- M41: Sadece çocuğum çalışıyor. 1400 lira alıyor, 1000 lira kiraya veriyoruz. Gömleğini gösteriyor. Bu 'teneke' diyor (gömleğini çöpten almış).

- M16: Mesela kışın sobayı günde 1 defa çalıştırıyoruz. Bir saat bile çalıştiramiyoruz sobayı.

- M65: Evde normalde çok ağır yiyecekler yapamıyoruz, sadece atıştıracak şeyler yiyebiliyoruz. Mesela kahvaltıllk şeyler. Bir şey pişirirsem bir çorba pişiriyorum ya da sadece pilav, öyle.

- M72: Her şey pahalı. Çünkü biz geldik para düşmüş; 1 Türkiye lirası 200 Suriye lirası. Ooo. Yani 10 lira 2000 Suriye lirası.

Maddi sorunları etkileyen bir diğer sorun iş piyasasından dişlanmadır. Uzun saatler çalışıp karşılığında düşük ücret almak, taşıdıkları vasıflara göre vasıfsız işlerde çalışmak, parça başı işler yapmak ya da düzensiz çalışmak bazı katılımcılar tarafından dile getirilmiştir. Kadın ve orta yaşın üzerindeki Suriyeliler ise iş piyasasına dâhil olmakta daha genç yaştakilere ve erkeklere göre geri planda kalmaktadırlar. Katılımcı kadınların büyük kısmı çalışma hayatına aktif olarak katılmasa da işsizlik meselesi kadınlar tarafından değil daha çok erkekler tarafından dile getirilmektedir.

- M65: (Kollarmn gösteriyor, kolundaki ütü makinasının izleri.). Ütü makinası ile yaralandım iş yerinde... O kadar çalışıyorum ki yorgunluktan bayılıyorum, makine kolumun üstünde kalıyor.

- M36: Evde yapılan işlerden yaptım, artık yapamıyorum. Gözüm kör oldu neredeyse. Bir de parça başına 20 kuruş veriyorlardı. Boşu boşuna çalışıyordum, sonra bıraktım.

- M2: Marangozluk yapıyorum. Günde 30 liraya 13-14 saat çalışıyorum. Masraflarım çıkmıyor.

Bazı katılımcılar gelirleri yetmediği için 2 vardiya çalıştıklarını beyan etmiştir. Bu durum bir insanın kaldırabileceğinden daha uzun çalışma saatleri boyunca çalışmalarına neden olmaktadır. 
- M14: Eşim işe gece 01:00'de gidiyor, ertesi gün saat akşam 17:0018:00'da geliyor, ne zaman uyuyacak. 4 bebek var yani. Firında çalış-yor. 2 vardiya çalışıyor. Mecbur.

Bir diğer sorun sigortasız çalışmak ve diğer çalışanlara göre düşük ücret almaktır.

- M11: Hayır, sigorta diye bir şey yok. Maaş farkll, ayda 400-500 lira fark oluyor. Çünkü onun artı sigortası var bizim yok. Çiftte 50 kuruş, 75 kuruş, 1 lira az veriyorlar. Biz de çalışmak zorundayız. Aslında olmaması gereken bir şey, lakin oluyor işte.

- M15: Mesela ben boncuk işi yapıyorum ya, Suriyelilere ayrn fiyat, Kürtlere ayrı fiyat, Türklere ayrı fiyat. Mesela benim eşim çalışıyor ya, onlara söylemiyor kimin ne kadar maaş aldığını.

Bazı katılımcılar kendi mesleklerini yapamadıkları için çalışamadıklarını belirtmişlerdir.

- M73: Çoğu uzman doktorlar, bilim adamlarn Avrupa'ya gitti. Uzman bilim adamları, profesörler vardı. Bunlar iş bekledi burada. Biz burada Türk devletinden bize vazife vermesini bekledik. Benim de 3 diplomam var. Herhangi bir dernekte ya da vakufta görevli olarak çalışmak istedim. Fakat henüz bir netice alamadım. Netice alamayınca ne oluyor, göç başlıyor. İnsanlar başka yerlere gitmek zorunda kalıyorlar.

Bazı katılımcılar iş ortamında kötü muameleye maruz kaldıklarından bahsetmiştir.

- M28: Suriyeliyim diye hakaret ederlerdi. Ben onlara bir şey yapmıyordum, sessizce çalışırdım. Ben korkarak çalışıyorum ama kendileri öyle... Şu işi sen yap, şöyle yapma, böyle yapma. Bir şey olunca sürekli hakaret, bağırma çağırma... İşyerinde tek Suriyeli olan bendim, sürekli konuşuyorlardı yanımda; Suriyeliler neden başımıza kalıyorlar, onların yüzünden biz mağdur oluyoruz, diye. Ben sesimi çıkartmazdım ama içimden çok yanardım, zoruma giderdi. Sesimi çıkartamazdım, iş yerinde çok hakaret ederlerdi bana. Sesimi çıkartamazdım, işime bakardım.

Bazı katılımcılar hasta ve yaşlı oldukları için kendilerine iş verilmediğini belirtmişlerdir.

- M17: Buraya geldiğimizde iş durumundan dolayı zorlandık.. Burada konfeksiyonda çalıştım ama şimdi burada bu yaşta iş olmuyor.

Katılımclar tarafından dile getirilen önemli sorun alanlarından biri de toplumdan gelen kötü davranışlar ve toplumdan dişlanmadır. Katı- 
lımcıların \%18'i toplumdan gelen kötü davranışları \%29'u da toplumdan dışlanma anlamına gelecek davranışları sorun alanı olarak dile getirmiştir. Bununla ilgili bazı beyanlara örnek olarak:

- M59: Türklerin davranışları iyi değil.

- M16: Mesela mahallemizde biri öldürüldü, sonra dediler ki bunu Suriyeli birisi öldürdü. Biz de bundan sonra korkar olduk. Artık dışarı çıkamıyorduk.

Katılımcı Suriyelilerin arasında Türk toplumundaki bazı insanların iyi bazılarının kötü davrandığı konusundaki söylem de yaygındır.

- M40: Bazıları iyi, bazıları kötü, bazıları bizden daha iyi. Bazıları da diyorlar ki; buraya gelip burayı bozdunuz, artık ülkenize dönün!

Suriyeli olduğu için dışlanmak ve ayrımcılığa uğramak katılımcı Suriyeliler tarafından sıklıkla dile getirilen bir durumdur.

- M60: Kötü muamele gördüm. Benim çocuklarım mahalledeki çocuklarla kavga ettiler. Onlarn ayırmak gerekiyordu. Sonra birisi geldi, bıçă̆ı vardr. Büyük biri geldi, çocuklarımı hem dövdü hem yere vurdu. Çocuklarımı oradan almasam belki çocuklarımı öldürecekti. O adam sonra bizim evimize geldi. Bir de sokaktaki gençler toplandı. Bizi silahla tehdit etmeye çalıştılar. O yüzden başka bir eve taşındık. Bizi bulmaya çalıştılar. Her yerde arıyorlardl. Sonra ben gidip devlete şikâyet ettim. Hiçbir şeye yaramadl, artık çocuklar korkuyorlardl.

Katılımcıların yaşadıkları bir diğer sorun alanı psikososyal sorunlardır. Katılımcıların \%76'sı çeşitli psikososyal sorunlar deneyimlemektedir. $\mathrm{Bu}$ psikososyal sorunlar kayıp ve travma yaşamak, sosyal izolasyon, olumsuz duygulanım, tükenmişlik, çaresizlik, göçün ne kadar süreceğiyle ilgili belirsizlik, kaçırılma korkusu, suç mağduru olmak, yakın kaybı, akrabalardan uzak kalmak, önyargılı ve yanlış söylemlere muhatap olma şeklinde deneyimlenmiştir. Öncelikle Suriye'den zorunlu göç ederek Türkiye'ye gelen katılımcıların bir kısmı çeşitli kayıp ve travmalar yaşadığı belirtilebilir. Daha önce yaşanılan evin kaybı, yakınlarını kaybetmek, statüsünü kaybetmek, vatansız kalmak gibi... Katılımcların \%22'si bu temayla ilgili sorunlar yaşadıklarını beyan etmiştir.

- M55: Çocuklarımın ölüm görüntüsü her gün gözümün önünden geçiyor.

- M28: ilk geldiğimde çok sıkıntılar yaşadım. Memleketimizi bıraktık, ölü çoktu. Annemi babamı özledim. Diyordum ki, bu başımıza neden geldi? 
Çok sıkıntılar geçirdim. Bu sıkıntı da beni yedi bitirdi. Bana hastalıklar getirdi. Şimdi çocuklarım evde, ufaklar, onları yalnız bırakıyorum ya hastalık oldu bende, mide, böbrek, bel hastası oldum. Onun için eşim işi bıraktırdl, şimdi biraz tedavi oldum. Şimdi yarım gün çalışıyorum.

Katılımcı Suriyeliler arasında sosyal izolasyon yaygin bir durumdur. Katılımcıların \%30'u sosyal anlamda izole bir hayat sürmektedir. Özellikle evde oturan ve dil bilmeyen Suriyeli kadınlar çok kısıtlı bir sosyal çevre içinde yaşamaktadır. Katılımcılara Türklerle arkadaşlık ilişkisi kurup kurmadıkları sorulduğunda birçoğu Türklerle görüşmediklerini, hatta onların kendilerinin arkadaşlı̆̆ını istemediklerini belirtmiştir.

- M18: Burada hiç akrabam yok, onlarla dertleşemiyorum, onlarla görüşemiyorum. Burada kimseyle görüşemiyorum, sadece işe gidiyorum ve işten sonra eve gelip yatıyorum.

Çoğu katılımcı olumsuz duygulanımı dile getirmiştir. Bazı ifadeler diğer sorunlarla bağlanarak anlatıldığı için onlar farklı başlıklarda ele alınmıştır. Olumsuz duygulanım ile ilgili bağımsız ifadeler \%5 sıklığında ele alınmıştır.

- M34: Kendimi kötü hissediyorum.

- M65: Psikolojim sifir gibi.

Katılımcıların \%20'si tükenmişlik durumu beyan etmiştir.

M29: Nefsim yorgun. Kendimi yorgun hissediyorum. Kalbim ölmüş.

M65: İstediğin her şey belki bende var ama tercüman bile aktaramayacak. Çünkü çok şeyler var.

Katılımcların \%13'ü çaresizlik durumu beyan etmiştir. Bu temaya bağlı beyanlar sorunların karşısında çözümsüz kalmak, kötü muameleye maruz kalsalar da resmî mercilere başvurarak hakkını arayamamak gibi durumları temsil etmektedir. Muayene için gittiği bir doktorun kendisine kötü muamele ettiğinden bahseden bir katılımcının beyanı aşağıda örnek olarak verilmiştir.

- G: Bunu şikâyet ettiniz mi peki?

- M28: Ne şikâyet edeceğim, koskoca doktoru nasıl şikâyet edeceğim? Doktor sonuçta kendisi. Ben burada bir garip vatandaşım. Vatandaş da değilim, göçmenim. Mülteciyim.

Çalıştırılan Suriyeli çocuklardan birinin annesinin beyanına göre patronun tokat atması sonucu, çocuğun bir kulağında işitme kaybı oluşmuştur. 
- G: Çocuğunuzun kulağına vurunca patronu bir yere şikâyet ettiniz mi?

- M60: Daha büyük sorunlar çıkmaması için şikâyet etmedik, korktuk, dedik ki; biz buraya misafir olarak geldik. Onlar şikâyet edersek daha kötü durumda kalacă̆gz. Korkumuzdan şikâyet etmedik.

Göçün süreciyle ilgili belirsizlik \%5’lik bir kısım katılımcı tarafından dile getirilmiştir. Göç sürecinin ne kadar süreceğiyle ilgili belirsizlik, hazırlıksız şekilde göç etmeye zemin hazırlamış hem de maddi ve manevi anlamda Türkiye'ye uyum sürecini zorlaştırmıştır. Katılımcıların \%7'si kaçırılma korkusu yaşadığını beyan etmiştir. Katılımcıların \%7'si de suç mağduru olduklarını dile getirilmiştir. Örnek:

- M57: Eşimin kardeşini kaçırdılar. 1.000 dolar aldılar serbest bırakmak için. Bir saat süre verdiler paranın gelmesi için. Saat akşam 19:00. Gece 23:00'den sonra bu çocuğ u unutun dediler... Bilmiyoruz kim olduklart$n$, para istediler... Polise söylemek faydasız... Meydanda durmuşlar, bu adamı biz alıyoruz, burada tanıdı̆̆ın var mi diye soruyorlar. Kimse ses çıkarmamış, sonra meydanın ortasında çocuğu alıp götürmüşler... Facebook'ta yazıyorlar. Böyle şeyler çok oluyor Esenyurt'ta.

Bazı katılımcılar göç etmeden önce kayıplar yaşamışken katılımcıların \%3'ü Türkiye'deyken bazı yakınlarını kaybetmiştir.

- M21: Buraya gelirken ben bebeğime hamileydim. Kocam Suriye'ye döndü. Ondan sonra kocamdan hiçbir haber alamadık. Şimdi büyük çocuğum çalışıyor, masraflara sadece o yardım ediyor... Gittiğinden bir ay sonra öldüğünü haber aldık ama kesin bir şey öğrenmedik.

Akrabalardan uzak kalmak en sik dile getirilen sorunlardan biridir. Katılımcıların \%29'u göç sonrası aile fertleri ve akrabalardan uzak kalmayı sorun olarak dile getirmiştir.

M73: Sıkıntılardan bir diğeri giriş çıkışlar. Türkiye'ye giren bir daha çıkamıyor, çıkarsa bir daha dönmesi problem oluyor. Akrabalar arasındaki bağımız koptu, annemizi babamızı göremiyoruz. Ĕ̆er varsa Suriye'de kalan ya da başka bir ülkede kalan, onlar bize gelemiyor. Kardeşlerimizle görüşemiyoruz. Sıla-i rahim olmuyor senelerce, belki 5 sene birbirimizi göremiyoruz, bu sikıntı oluyor. İnsanlar birbirini göremeyince bu alanda insan kaçakçlarn türüyor. Bu insanlar Türkiye'ye olsun, Avrupa'ya olsun insanları getirmek için büyük paralar altyorlar.

Toplumda Suriyelilere maaş bağlandığı, onların sınavsız şekilde üniversiteye yerleştirildiği, faturalarının devlet tarafından ödendiği, seçim- 
lerde oy kullandıkları gibi önyargılı ve yanlış söylemler dolaşmaktadır. Önyargı katılımcların \%1'ini temsil eden bir katılımcı tarafından dile getirilmiştir. Suriyelilere yönelik hizmet veren bir sivil toplum kuruluşunda görevli olan bu katılımcı durumu şöyle dile getirmiştir:

M58: Öncelikle hiçbir resmî yerden bize yardım yok. Öncelikle ben kendi adıma ve burada gördüğüm yüzlerce, binlerce Suriyeli ailenin problemleri adına bahsetmek istiyorum. Buraya gelen aileler olarak biz destek almiyoruz. Kendi imkânlarımızla yaşıyoruz... Türkiye'de insanlardan, komşularımızdan bunları görüyoruz, sanki devlet bize maaş bağhlyor, devlet yardımlarda bulunuyor, çocuklarımıza burs veriyor, sağllkla ilgili çok büyük yardımlar yapıyor gibi...

Katılımcıların \%21'i sağlık sorunlarını bir sorun alanı olarak dile getirmiştir. Bazı katılımcıların kendisinde ve ya aile fertlerinden birinde sağlık sorunu bulunmaktadır. Bu katılımcılarda engellilik, kronik hastalık, beslenme yetersizliğinden kaynaklanan sağlık sorunları ve uzun çalışma saatlerinden kaynaklanan sağlık sorunlarına rastlanmıştır. Bazı engellilik durumları Suriye'deki çatışmalarda yaralanma sebebiyle gerçekleşmiştir. Dile getirilen bir diğer sorun sağlık hizmetlerine erişim sorunudur. \%9 sıklığında dile getirilen bu sorun, dil bilmemek, geçerli bir kimlik belgesine sahip olmamak, maddi durum ve kültürel faktörlerden etkilenmektedir.

Katılımcların \%33'ü tarafından dile getirilen önemli bir sorun da barınma sorunudur. Aylık gelirin büyük bir kısmının barınma masrafına ayrıldığı sıklıkla dile getirilirken, buna rağmen kötü şartlardaki evlerde yaşamaktadırlar. Bazı katılımcılar Suriyeli oldukları için ev bulmakta zorlandıklarını, ev kiralarının Suriyeliler geldiği için arttığını belirtmektedir. Kiraların yüksek olmasından dolayı bazı Suriyeliler birkaç aile beraber yaşamaktadır. Bazı katılımcılar ev sahiplerinin kendilerinin günlük hayatına müdahale ettiklerini de dile getirmişlerdir.

- M60: Ilk geldiğimiz zaman benim kardeşlerim buradayd, bir süre onlarla kaldım. Sonra başka bir eve taşındık. O ev bodrum katıydı, çok kötüydü, su alıyordu. Çocuklarım her gün hasta oluyordu.

- M73: Buraya ilk geldiğimizde ev tutmada sıkıntı yaşadık. Çünkü ev fiyatları yüksekti. Bazı ev sahipleri Suriyelilere ev vermiyor.

- M18: Evde üç aile kahıoruz, karı koca bir odadayız, diğer arkadaşım karı koca bir odada, çocuklar da salonda yatıyor. 
Ev içi sorunlar bir diğer sorun alanıdır. \%16'lık bir kısım katılımcı tarafından dile getirilen bu sorun alanında aile içi şiddet ve çocuk bakımıyla ilgili sorunlar beraber ele alınmıştır.

- M28: Sikıntıllyız, evde sürekli stres ve sikıntı. Küslük, darginlık var, konuşmuyoruz... Tabii maddiyat çok etkiliyor. Şimdi mesela, eşim çalışmıyor, evde. Ben öğleden sonra işe gittiğimde kendisinde sıkıntı oluyor. Niye ben çalışıyorum da kendi evde oturuyor diye.

- M39: Ailede babanın olması çok önemlidir. Yönlendirir, nasihat verir. Şimdi babaları yokken çocuklarla çok zorlanıyoruz.

Eğitim sorunu bir diğer önemli sorun alanıdır. Katılımcların \%14'ü bu sorunu dile getirmiştir. Okullarda öğretmenlerin çocuklarla yeterince ilgilenmemesi ve eğitime erişim sorunu bu tema altında dile getirilmiştir. Bu tema altında belge eksikliğinden dolayı çocuklarını okula gönderememek, kimlik belgesi numarasının 98'li olması ya da kimlik belgesinin farklı bir şehirde kayıtlı olmasından dolayı da eğitim alamadıklarını belirten katılımcıların yanında, dil eğitim kursları için mesafe ve yol parası ya da kocanın izin vermemesi gibi sebeplerle bazı kadınların dil eğitim kurslarından faydalanamaması ele alınmıştır.

Bir diğer sorun alanı çocukların çalıştırılmasıdır. \%9'luk bir kesim çocuklarının çalışmak zorunda kaldıkları için eğitim hayatını yarıda bıraktığını beyan etmiştir

- M10: En büyük oğlum 14 yaşında. Şimdi çalışıyor zorunlu olarak. Çocuğum ortacillk yapıyor konfeksiyonda.

Katılımcıların \%30'luk bir kısmı Türkiye'de yaşamaya uyum sağlamakta zorlanmıştır ve hatta hâlâ uyum sağlamakta zorlanmaktadır. Bu durumun üzerinde hayat şartları, kültürel farklılıklar, vatan hasreti, ekonomik zorluklar ve dil gibi faktörler etkilidir.

M9: İstanbul'un kalabalık oluşu Şam'a biraz benziyor. Burada çok açık giyinen var, biz mesela çıkıyoruz, (Fatih'te) Fevzipaşa Caddesi'ne çok açı giyinen var, bizde böyle yoktu. Bizde bir yer vardı öyle, biz çok gitmezdik oraya... Güzel ama çok pahal, bizim köyümüzde hayat böyle pahal değildi. Yaşamak zor burada. Çocuğum nereye gitse arkasındayım. Bir de burada içki var, korku var, bir şey yaparlarsa oğluma diye korkuyorum. Önceden bir şehirde otururduk, böyle şeyler yoktu. Burada açı giyinme var kızlarda. Burada aileyi toparlayacaksın. 
Sosyal destek kişilerin günlük hayat zorluklarıyla baş etmesine yardımcı olan önemli bir etkendir. Katılımcların \%18'lik bir kısmı hiçbir yerden sosyal destek almadıklarım beyan etmiştir.

- M46: Kimseden bilgi ya da yardim alamıyoruz. İki defa hastaneye gittim. Türkçe bilmediğim için oradan kovdular. Hiç kimseden yardım ya da bilgi alamiyorum.

Sosyal destek almamanın üzerindeki bir etken sosyal destek ve sosyal hizmet konusunda bilgi eksikliğidir. Katılımcıların \%11'lik bir kısmı nereden sosyal destek ve sosyal hizmet alabilecekleri hakkında bilgi sahibi değildir.

- M58: Ihtiyaç antnda bize destek olacak sosyal kurumlar yok. Böyle gerekli yerlerle, kişilerle, memurlarla irtibatımız yok. Böyle hakkımız hukukumuz var mı haberimiz yok. Bilgimiz yok.

\section{Tartışma}

Bu çalışmaya göre Suriyeli sığınmacıların Türkiye'de yaşadığı sorunlar çok geniş bir yelpaze oluşturmaktadır. Sorun temaları temel ihtiyaçlarını karşılama, toplum tarafından saygı ve değer görme, topluma katılım gibi çeşitli alanlarla ilgilidir. Savaş ve zorunlu göç sebebiyle ortaya çıkan maddi ve manevi kayıplar ve travmalar karşılaşılan yeni sorunlarla baş etmeyi zorlaştırmaktadır.

Farklı bir ülkeye göç etmekten kaynaklanan gelinen ülkenin dilini bilmemek diğer sorunları besleyen önemli bir ana sorundur. Katılımcların büyük çoğunluğu Türkçe bilmemektedir ya da kısıtlı düzeyde Türkçe bilmektedir. Bu durum günlük hayatı, çalışma hayatını ve resmî dairelerle iletişimi etkilemektedir. Sığınmacılar kendileriyle ilgili mevzuata da hâkim olmadıkları için çeşitli hak ve ödevlerinden haberdar olamamaktadır. Bu açıdan kayıt olma, kimlik belgesi edinme, hastane, okul gibi yerlerden kamu hizmeti alma hususlarında oldukça zorlanmaktadırlar. Bu durum Suriyelilere kamu hizmeti veren personeli de olumsuz yönde etkilemektedir. Tercüman olan kurumlarda işler görece daha kolay olsa da tercüman olmayan kurumlar açısından iş zorlaşmaktadır. Dil bilmemek Suriyeli kadınları daha izole bir hayata mahkûm etmektedir. Suriyeli kadınlar açısından Suriyeli erkeklerin korumacı tutumunun da bunun üzerine etken olduğu gözlenmiştir. 
Katılımcıların resmî dairelerdeki işleriyle ilgili yaşadıkları en önemli sorun kimlik belgesi sorunudur. Suriyeliler Türkiye'ye ilk geldiklerinde kendilerine misafir olduklarını gösteren bir kart verilmiştir. Daha sonra Suriyeliler kamu idaresi tarafından kayıt olmaya teşvik edilmiş ve bulundukları şehirde geçerli olan ve $98^{\prime}$ le başlayan kimlik numarası olan kimlik belgesi verilmiştir. Bu uygulama yeniden değiştirilmiş ve bu sefer kamu idaresi tarafından 99'la başlayan 11 haneli kimlik numarası olan yeni bir kimlik belgesi verilmeye başlanmıştır. Bazı katılımcılar ilgili kimlik belgesine sahip değilken, bazıları farklı şehirde kayıtlı kimlik belgesine, bazıları da 98'le başlayan kimlik numaralı kimlik belgesine sahiptir. Bu katılımcılar kimlik belgesi almakta, 98 ile başlayan kimlik numaralı kimlik belgesi yerine, 99'la başlayan kimlik numaralı kimlik belgesi almakta zorlandıklarını ya da kayıtlarını İstanbul'a almakta zorlandıklarını beyan etmiştir. Kimlik belgesi sorunu önemli bir meseledir çünkü kişileri kamu hizmeti almaktan mahrum etmektedir. Bir vakada bir kadın başka bir kadının kimlik belgesi ile doğum yapmıştır. Dolayısıyla kendi çocuğunun kimlik belgesinde başka bir kadının ismi yazmaktadır. Kimlik belgesi almayı zorlaştıran önemli sebeplerden biri müracaat için istenen belgelerin bölgeden bölgeye değişmesidir. İlaveten bazı Suriyeliler kimlik belgesi almak için müracaat ettiklerinde kendilerinden üzerlerine kayıtlı fatura ve ikametgâh istendiğini beyan etmiştir. Ancak, kimlik belgesi olmayan birinin bunları edinmesi imkânsızdır. Kimlik belgesi alırken istenen belgelerin de bölgeden bölgeye değişmesi hizmet verenler açısından uygulama farklılı̆̆ı olduğunu göstermektedir. Bu durum hizmet veren ve hizmet alanlar açısından dezenformasyon olduğunu göstermektedir.

Dil sorununun etkisiyle Suriyelilerin daha çok bedensel emeğin yoğun olarak verildiği konfeksiyon, inşaat, lokantacılık, marangozluk, ayakkabıcılık, fırıncılık, elektrikçilik gibi işlere yöneldikleri görülmüştür. Katılımcılar ve çalıştırılan çocuklar yoğun olarak konfeksiyon alanında çalışmaktadır. Konfeksiyon kayıtsız elemanların yoğun olarak çalıştı̆̆ı, parça başı ücretlendirme yapıldığı ve ödemelerin zaman zaman düzensiz yapıldı̆̆ı, çalışma saatlerinin zaman zaman uzayabildiği bir çalışma alanıdır. Bu durum katılımcılar tarafından dile getirilmiştir. Kadınlar arasında görülen en yaygın iş konfeksiyonculuk ve evde yapılan parça başı elişleridir. Bu çalışma tarzı da oldukça düşük gelir getirmektedir. 
Katılımcılar arasında orta yaşın sonlarında iş bulamayan kesim de hurdacılık yaptıklarını ya da çöpten eşya topladıklarını beyan etmiştir. Yükseköğretim mezunu olanlar da kendi mesleklerini dil ve diploma denkliği alamamaktan dolayı yapamamaktadır. Akdeniz (2014)'de buna benzer sorunları dile getirmiştir. İstanbul'daki sığınmacıların çalışma hayatıyla ilgili yaptığı araştırmada, Suriyeli sığınmacıların aynı işi yapan Türk işçilere kıyasla daha düşük ücret alıp daha fazla süre çalıştıklarını, ücretlerinin işveren tarafından eksik veya düzensiz verildiğini ya da hiç verilmediğini, çoğunun sigortasız ve eğitimlerine göre daha vasıfsız işlerde çalıştıklarını, Türk işçilerin de işsizlik ve genel anlamda iş piyasasında ücretlerin düşmesinden dolayı Suriyelileri sorumlu tuttuklarını belirtmiştir. Yıldırımalp, İslamoğlu ve İyem (2017) benzer şekilde İstanbul'daki Suriyeli sığınmacılar hakkında yaptıkları çalışmada, Suriyelilerin sosyal güvenceden yoksun olarak günübirlik işlerde çalıştıklarını, zor işlerde görevlendirildiklerini, düşük ücret aldıklarını, çalışma ortamında taciz ve şiddete maruz kaldıklarını belirtmiştir. Çetin (2016) Adana ve Mersin'de yaşayan Suriyeliler hakkında yaptığı çalışmada Suriyelilerin işsizlikle boğuştuğunu ya da meslek sahibi olsalar bile vasıfsız işlerde çalıştıklarını, uzun saatler boyu çalışıp düşük ücret aldıklarını belirtmiştir. Valtonen'e göre çalışma hayatına katılmak sosyal vatandaşlık ve topluma tam katılımdan ayrı düşünülemez. Refah devletinde göçmenlerin iş piyasasından dışlanması, bu insanların sosyal adalete dayanmayan bir vatandaşlık durumunda bulunmalarına ve toplumla bütünleşememelerine neden olur (Valtonen, 2008, s.47).

Maddi anlamda kimi zaman hazırlıklı kimi zaman hazırlıksız olarak gelen sığınmacılar açısından ekonomik sorunlar ön plandadır. Çalışmanın yapıldığı vakıftan maddi yardım ve ikinci el eşya almaya gelen bu katılımcılar genel olarak Suriye'de refah içinde yaşadıklarını, İstanbul'daki gelirlerinin ise geçinmeye yetmediğini, Suriye'deki çalışma saatlerinin daha kısa olduğunu, İstanbul'da ise alım güçlerinin düşük olduğunu, kiraların yüksek olduğunu ve faturaları zorlukla ödediklerini beyan etmişlerdir. Maddi sorunların altında Suriyelilerin daha az gelir getiren işlerde çalışması, kadınların çalışma hayatına katılamamaları ya da düşük gelirli işlerde çalışması etkendir. Orta yaşın sonlarındaki ve üstündeki kişiler, engelliler ve yaşlılar da çalışma hayatına yeterince katılamamaktadır. Kirayı verebilmek için temel ihtiyaçlardan kısmak yaygın 
bir durumdur. Ekonomik sorunlar yine çocukların çalıştırılmasına bunun sonucunda eğitimden mahrum kalmalarına sebep olmaktadır.

Ekonomik sorunların diğer uzantısı barınma sorunlarıdır. Bazı katılımcılar birkaç aile beraber yaşadıklarını beyan ederken, katılımcılar yaygın olarak kötü şartlardaki evlerde yaşadıklarını buna rağmen yüksek kira ödediklerini beyan etmiştir. Yakın akrabalarla birkaç aile iç içe yaşamanın, özel alan kalmaması ve çocuk yetiştirirken zorlanmak gibi ev içi sorunlara sebep olduğunu bazı katılımcılar belirtmiştir. Esin, Ardıç, Nar, Yıldırım ve Sunal (2014) tarafından İstanbul'un bir bölgesinde yaşayan Suriyeli 55 aile ve 248 birey üzerinde yapılan bir araştırmada ziyaret edilen evlerde düşük gelir, sadece temel gereksinimleri satın alabilme, yaşanılan alanın kirli olması, gıda saklanmasında kısıtlılık, kötü koku, temiz su ve kanalizasyondan faydalanma açısından kısıtlılık, yetersiz ısıtma ve soğutma, bina giriş çıkışlarının yetersiz olması, hayat alanının dağınık ve kalabalık olmasının yanı sıra evlerin \%63,7'sinde böcek ve kemiricilere, \%95,6'sında ise küfe rastlanmıştır.

Toplumda Suriyelilere maaş bağlandığına yönelik yanlış bilgiler dolaşsa da bu durum gerçeğe aykırıdır. Polis Akademisi tarafından yayımlanan ve Türkiye'deki Suriyelilerle ilgili önyargıların gerçekliğini sınayan bir raporda, toplumda Suriyeliler yüzünden Türkiye'deki işsizliğin artt1ğı, Türkiye Cumhuriyeti vatandaşlarına yönelik sosyal yardımların azaldığı, sağlık hizmetlerindeki kalitenin düştüğü, Suriyelilerin ekonomiye zarar verdiğii, asayiş sorunlarına yol açtıkları gibi önyargıların bulunduğu ama bu önyargılar incelendiğinde gerçeği yansıtmadığı beyan edilmiştir (Taştan, Haklı ve Osmanoğlu, 2017).

Katılımcı Suriyelilerin yaklaşık yarısı düzenli olarak bir yerden yardım alamadıklarını beyan etmiştir. Geçerli kimlik belgesi sahibi olamamak da bu durumu etkilemektedir.

Dil bilmemekle etkileşim halinde olan bir diğer sorun psikososyal sorunlardır. Öncelikle Türk toplumu ve Suriyeliler yeterince etkileşime girmemektedir. Katılımcılar çoğunlukla Türklerle arkadaş olmak, komşuluk yapmak ve birbirine gidip gelmek gibi sosyal etkileşimlere girememektedir. Bazı katılımcılarla etkileşim halinde olanlar genelde Arapça veya Kürtçe bilen Türk vatandaşlarıdır. Ortak dil bilmeden arkadaşlık veya komşuluk etmek, birbirine gidip gelmek gibi etkileşimler nadir olarak görülmektedir. Doğan ve Gürbüz (2018) yaptıkları çalışmada be- 
lediye kurslarında Türkçe öğrenen Suriyeli kadınlar Türk toplumunun yargısından dolayı dil öğrenseler de Türklerle komşuluk ilişkilerini geliştiremediklerini beyan etmiştir. $\mathrm{O}$ halde Türk toplumuyla Arapça ve Kürtçe üzerinden etkileşime girmek iki tarafın arasındaki etnik ve dinî yakınlıktan kaynaklanıyor olabilir.

Türk toplumundan kötü davranış ve dışlanma ile karşılaştığını belirten Suriyeliler bulunmaktadır. Kimisi de dil bilmediği için izole bir hayat sürmekte ve bu tür etkileşimlerden kaçınmaktadır. Suriyeliler genellikle aile fertleriyle ve diğer Suriyelilerle görüşmekte, yaşanılan sorunlar aile içi yardımlaşma ve diğer Suriyelilerden gelen enformasyonla halledilmeye çalışılmaktadır. Ünal (2014) da buna benzer olarak, Suriyeli sığınmacılar hakkında internette yapılan yorumları incelediği çalışmasında, Türk toplumunda Suriyelilerin ulusal güvenliği ve ülkenin düzenini tehdit ettiğini, ekonomik kaynaklardan Suriyelilerin faydalanmasından duyulan rahatsızlıktan ötürü ırkçı, ayrımcı ve düşmanlık içeren söylemlerin yaygın olduğunu belirtmiştir. Suriyeli kadınlarla ilgili Türk erkeklerine ikinci eş olma hususundaki söylemlerin de Suriyeli kadınların toplumla bütünleşmesini etkileyebilmektedir (Küçükşen, 2017). Sosyal ve kültürel farklılıklar, artan işsizlik, yerel halkla Suriyeliler arasında negatif etkileşim oluşturması karşısında Suriyeli sığınmacılar kente uyum sağlamak yerine izole hayat sürmektedir (Karasu, 2016). Karasu (2018) da özellikle Suriyelilerin nüfusunun kentin nüfusuna yakın olduğu Urfa'daki çalışmasında Türk toplumunun ağırlıklı olarak Suriyeli bir komşu istemediğini, işsizlik, çalışma ücretlerinin düşmesi, suç oranının artması, ahlaki bozulma gibi konularda Suriyeli sığınmacıların suçland1ğını belirtmektedir. Yıldırımalp vd. (2017) kamplardan ayrılıp İstanbul'a yerleşen Suriyelilerin toplumsal kabul ve uyumuyla ilgili yaptıkları çalışmada Suriyelilerin çoğunlukla Suriyelilerle görüştügünü, sosyal hayatta ayrımcllıkla karşılaştıkları için kendilerini izole ettiklerini belirtmişlerdir.

Yalnızlık, sosyal izolasyon yaygın olarak görülürken bununla beraber duygusal anlamda tükenmişlik, sorunlar karşısında çaresizlik yaygın olarak dile getirilmektedir. Kayıp ve travma yaşamak yaygın olarak görülmektedir. Savaşa maruz kalmak, yaralanmak, sağlığını, sevdiklerini, evini, mal varlığını, vatanını kaybetmek gibi travmatik kayıplara ek olarak göç sonrası aile fertlerinin ve akrabalarının birbirinden ayrılması 
katılımcı Suriyelileri derinden etkilemektedir. Özen ve Cerit (2018) de Suriyeli sığınmacılarla ilgili Harvard Travma Envanteri ve Beck Depresyon Ölçeği uygulayarak yaptıkları çalışmada savaş sonrası karşılaşılan travmatik olay sayısı arttıkça Suriyeli sığınmacıların travma puanının yükseldiğini, sığınmacıların üçte ikisinin hafif, orta veya yüksek düzeyde depresif semptomlar gösterdiğini belirtmiştir.

Vatanlarına geri dönüşle ilgili belirsizlik kişileri geçicilik ve kalıcılık arasında arafta bırakmaktadır. Nasılsa döneceğiz düşüncesiyle dil öğrenilmemekte bunun yanında evimiz yıkıldı, savaş var nereye döneceğiz düşüncesi dile getirilmektedir. Kimisi farklı bir ülkeye gitmeyi düşünürken, kimisi de halen bir gün geri dönmeyi hayal etmektedir.

Ev içi şiddet, çocuk yetiştirme sorunları gibi ev içi sorunlar yaygın olmasa da dile getirilmiştir. Suç mağduru olmak, kaçırılma korkusu da yaygın olmasa da dile getirilen bir diğer sorundur. Sağlık sorunları ve sağlık hizmetlerine erişim sorunu dile getirilen diğer sorundur. Sağlık hizmetlerine erişimi, kimlik belgesi sahibi olmamak ve dil bilmemek etkilemektedir.

Eğitimle ilgili dile getirilen sorunlara bakılırsa maddi imkânsızlıklar yetişkinler açısından eğitim kaynağına erişememeyi, çocuk ve gençler açısından eğitimden uzak kalmayı doğurmaktadır. Katılımcılar arasında çocukların çalıştırılması çok yaygın değilse de göz ardı edilemeyecek durumdadır. Çalıştırılan çocukların erkek çocuklar olduğu görülmüştür. Bahadır ve Uçku (2016)'nun çalıştırılan Suriyeli çocuklar hakkında yaptıkları çalışmada, erkek çocukların çalışma hayatına daha fazla katıldığı görülmüştür.

Dile getirilen yaygın sorunlardan biri de Türkiye'ye alışma, uyum sağlama konusundaki sorunlardır. Göç hazırlıklı yapılsa bile birçok uyum sürecini beraberinde getirirken hazırlıksız şekilde göç eden s1ğınmacılar için uyum meselesi zorlaşmaktadır. Sluzki göçü evrelere ayırdığı modelinde göçün hemen sonrasında temel ihtiyaçların giderilmesine odaklanıldığını, karşılaşılan durum ailenin baş etme gücünü aşıyorsa çeşitli psikolojik sıkıntılar ortaya çıkabildiğini belirtir. Uyum süreci kişiden kişiye ve aileden aileye farklılık gösterir. Bireylerin geri dönme umudunu taşıması gelinen topluma uyum sağlanmasını negatif yönde etkileyebilir. Bireylerin duygusal ihtiyaçları öne çıarken reddedilme, 
dışlanma gibi negatif durumlar benlik bütünlüklerini etkileyebilir (Sluzki, 1979).

Mawani'ye göre göçmenler bireysel veya sistem tarafından sosyal dışlanmaya uğrama riski altındadır. Sosyal dışlanma da iş, eğitim, barınma gibi fırsatlara erişimi kısıtlamakta, bireylerin hayatları üzerindeki kontrol duygusunu baltalamakta ve çeşitli maddi ve manevi sorunlara sebep olmaktadır (Mawani, 2014, s.31-32). Valtonen'in aktardığı Amerika, Avustralya, Kanada ve Fransa'da yapılan çalışmalara göre de, ikinci kuşak göçmenler bile hayatlarının hepsinde ya da büyük bir kısmında ev sahibi ülkede yaşasalar da ciddi oranda sosyal dişlanma problemleriyle karşı karşıya kalmaktadırlar (Valtonen, 2008, s.139).

Katılımcıların yaklaşık beşte biri hiçbir yerden sosyal destek alamadıkların belirtirken, azımsanmayacak bir kısmı da sosyal destek ve sosyal hizmet hakkında bilgi sahibi değildir. Sosyal hizmetin ne olduğu sorulduğunda katılımcıların hiçbiri sosyal hizmeti bilmediğini beyan etmiştir. Coşkun ve Yılmaz (2018) benzer şekilde Düzce'de sığınmacılara yönelik yaptıkları çalışmada, sığınmacıların sosyal destek ve sosyal hizmetlere ulaşamadığını belirtmektedirler. Bu durum sığınmacıların psikososyal ve ekonomik sorunlarının etkisine daha da ağırlaştırmaktadır.

\section{Sonuç}

Suriyeli sığınmacıların belirttiği sorunlar çeşitli olduğundan değerlendirme yaparken çok yönlü bakmak gerekmektedir. Öncelikle belirtilmelidir ki problemlerin çoğunu dil sorunu beslemektedir. Türkçe bilmeyen ya da kısıtlı derecede Türkçe bilen sığınmacılar kanuni hak ve ödevlerinden haberdar olamamakta, resmî işlerini halletmekte zorlanmaktadır. $\mathrm{Bu}$ durum geçerli kimlik belgesi edinme, kamudan hizmet alma, sosyal yardım ve sosyal hizmetlerden yararlanma gibi alanlarda sığınmacıları etkilemektedir. Dil bilmemeyle bağlantılı olarak Suriyeli sığınmacılar, özellikle kadınlar topluma daha az katılım sağlayıp sosyal hayattan izole olmaktadır. Çalışan Suriyeliler daha çok bedensel emek verilen, uzun saatler çalışılan ve karşılığında düşük ücret alınan işlerde çalışmaktadır. Vasıflı Suriyeliler ise kendi mesleklerine uygun işleri yapamamaktadır. İş yerinde kötü muamele görmek de dile getirilen sorunlardan biridir. 
Ekonomik sorunlar, bağlantılı olarak barınma sorunlarını beraberinde getirmekte, sığınmacılar temel ihtiyaçlarından kısarak gelirlerinin çoğunu kiraya harcamaktadır. Yanlarında birikim getirememek, kısıtlı bir birikim getirmek, birikimlerini göç ederken ya da geldikten sonra tüketmiş olmak ve Suriye parasının değerinin düşmesi ekonomik sorunlarda etkendir.

Sıklıkla dile getirilen kimlik belgesi sorunu, kamudan eğitim, sağlık, sosyal yardım gibi çeşitli hizmetleri almayı doğrudan etkilemektedir. Sığınmacıların düzenli şekilde sosyal yardım alması toplumda zannedildiğinin aksine yaygın bir uygulama değildir.

Yaşanılan kayıp ve travmalar, zorlu hayat şartları ve sosyal izolasyon sığınmacılarda tükenmişlik oluşturmaktadır. Akrabalık bağlarına önem veren Suriyeliler, aile fertleri ve yakın akrabalardan uzak kalmayı önemli bir sorun olarak görmektedir. Bu durum sığınmacıların sosyal destek mekanizmalarını zayıflatmaktadır. Göç süreciyle ilgili belirsizlik, hayat şartları, kültürel farklılıklar ve vatan hasreti gelinen topluma uyumu etkilemektedir. Toplumdan gelen kötü davranışlar, önyargı ve Türkçe bilmemek Türk toplumu ile etkileşimi zayıflamakta, Suriyeliler bu konuda çekimser kalmaktadır.

Belirlenen sorun alanlarından yola çıkılarak şu öneriler getirilebilir:

1. Sığınmacıların Türkçe öğrenmesi için kamu ve sivil toplum kuruluşları tarafından yaygın eğitim kursları sağlanmalıdır. Bu kurslara katı$1 \mathrm{~m}$ için sığınmacıların sıklıkla başvurduğu kurumlarda sığınmacılara yönelik bilgilendirme ve yönlendirme yapılmalıdır. Hatta Türkçe öğrenenlerin istihdamına destek olunarak sığınmacıların Türkçe öğrenmesi teşvik edilmelidir. Dil öğrenmek sığınmacıların topluma katılımını arttıracağı ve eğitim hizmetleri, sağlık hizmetleri ve sosyal hizmetlerden faydalanmalarını kolaylaştıracağı için, çeşitli psikososyal sorunlarının üstesinden gelmelerine yardımcı olacaktır.

2. Sığınmacıların iş piyasasına katılımları desteklenmeli, eğitimlerine ve kişisel niteliklerine uygun işlerde istihdam edilmeleri için çalışmalar yapılmalıdır. Bu durum tedrici olarak sığınmacıların maddi yetersizliklerini ve sosyal yardıma ihtiyaç duymalarını azaltacaktır.

3. Sığınmacılar topluma katılım, yasal hak ve sorumluluklar, Türkiye'nin toplumsal yapısı ve kendileri için gerekli olan kurumsal ve 
sosyal kaynaklar hakkında bilgilendirilmelidir. Bu durum sığınmac1ların toplumla karşılıklı uyum sağlamalarını destekleyebilir.

4. Sığınmacı ve mültecilerle ilgili toplumda dolaşan kötü propagandaya malzeme teşkil eden yanlış bilgiler ayıklanmalı, toplumda yaygın olarak kullanılan haberleşme kaynaklarında topluma doğru bilgilendirme yapılmalıdır. Sığınmacı ve mültecilerle ilgili çalışan kamu kurumları ve sivil toplum kuruluşları halkı doğru bilgilendirici dokümanlar yayınlanmalıdır. Yine ilgili kuruluşlar tarafından sığınmacıların topluma sağladıkları faydalar da vurgulanmalıdır. Bu durum toplumdan gelen dışlayıcı davranışları ve kötü muameleyi azaltabilir.

5. Kamu çalışanları sı̆̆ınmacılar ve mültecilere yönelik mevzuat ve bu kişilerin hakları konusunda bilgilendirilmelidir. Bu durum sığınmaclların teori ve uygulama arasındaki farklılıklardan kaynaklanan hak kayıplarını azaltabilir. Böylece ilgili yasanın hedeflediği sosyal uyum daha hızlı ve daha etkin şekilde gerçekleştirilebilir. 


\title{
EXTENDED ABSTRACT
}

\section{The Problems of Syrian Refugees Faced After Migration to Turkey: Case of Istanbul}

\author{
Güler Güneş Aslan - Fethi Güngör
}

Yalova University

Asylum-seeking migration is one of the important social events that shaped the $21^{\text {st }}$ century. Human societies migrate to different countries due to war, internal conflicts, political conflicts and discrimination by public authority. Turkey is one of several countries that is hosting millions of Syrian refugees fleeing the war environment created by various organizations and countries. As of the end of 2018 there are Syrian refugees in almost every city in Turkey.

In this study, the problems of Syrian refugees living in Istanbul were examined. In-depth interviews were conducted with 76 Syrian asylum seekers accompanied by Turkish, Arabic and Kurdish translators. The data obtained from the interviews were analyzed and devoted to themes by using the MAXQDA 2018 qualitative data analysis program. Thus, it was ensured that Syrian refugees were able to reflect their experiences and problems by their own perspective while living in Istanbul. Based on the data collected in the field; some problem themes are presented in the findings and discussion section; such as not knowing the language of the country, encountering obstacles in official transactions, exclusion from the labor market and society, living, housing, health, education and adjustment problems, not being able to receive social services and social support. Solution suggestions for the problems are listed in the conclusion section.

The findings of the study can be summarized as follows:

In this research, -in order to overcome the problem of trust- 76 Syrian refugees were collected from the Syrian Nur Association and the Damascus Scholars Foundation. The group which consists of 52 female and 24 male refugees, are mostly in the 19-59 age range. Among these participants, only a few were able to learn Turkish. 
$21 \%$ of the respondents found that they faced obstacles in official transactions, $18 \%$ found it difficult to obtain identity documents, $11 \%$ said they could not bring official documents such as diplomas, official marriage certificates from Syria $68 \%$ experienced financial problems, $29 \%$ of them were excluded from society, $30 \%$ had an isolated social life, $20 \%$ had burnout, $13 \%$ experienced helplessness, $29 \%$ had suffered from being away from family members and relatives, $16 \%$ of them experienced domestic conflicts, $21 \%$ could not solve their health problems, 33\% experienced housing problems, $14 \%$ did not have access to education services, $18 \%$ did not receive social support from anywhere and $11 \%$ stated that they do not know how to benefit from social services.

As the problems stated by the Syrian refugees are different, it is necessary to look at the various aspects of the evaluation. First of all, it should be noted that most of the problems are derived from the language problem. Refugees who do not speak Turkish or who have limited Turkish skills cannot be informed about their legal rights and duties and have difficulty in handling their official affairs. This affects refugees in areas such as obtaining valid identity documents, public services, social assistance and social services. In connection with the language, Syrian refugees, especially women, are isolated from the social life by providing less participation to society. The working Syrians are mostly employed in the labor force, who work long hours and receive low wages. Qualified Syrians are not able to do their jobs properly. Abuse in the workplace is one of the problems raised.

Economic problems bring along housing problems, and refugees spend most of their income on rent by reducing their basic needs. Not being able to bring along their savings or to bring a limited amount of their savings, spending their savings while on migration or after their arrival and the devaluation of Syrian money are major factors in economic problems.

Often the problem of the identity document directly affects the provision of various services such as public education, health and social assistance. It is not a common practice for refugees to receive regular social assistance, as opposed to what is believed in society.

Losses and traumas, difficult life conditions and social isolation is exhausting for refugees. Syrians who care about family ties, being away 
from family members and close relatives are considered to be an important problem. This situation weakens the social support mechanisms of refugees. The uncertainty about the migration process, life conditions, cultural differences and homesickness affects the adaptation to the society. Misconduct from the community, prejudice and the problem of language have weakened their interaction with Turkish society and Syrians are abstaining in this regard.

Based on the identified problems, the following recommendations can be made:

1. Common education courses should be provided by public and non-governmental organizations for the refugees to learn Turkish. In order to ensure participation in these courses, refugees should be informed and guided in institutions refugees often apply to. In fact, the refugees should be encouraged to learn Turkish by supporting the employment of Turkish learners. Learning a language will help them to overcome various psychosocial problems, as it will increase the participation of refugees in society and make it easier for them to benefit from educational services, health care and social services.

2. Refugees should be encouraged to participate in the labor market and initiatives should be taken in order to be employ them in jobs appropriate to their training and personal qualifications. This will gradually reduce the need for refugees' financial insufficiencies and social assistance.

3. Refugees should be informed about participation to society, the legal rights and responsibilities, Turkey's social structure and the institutional and social resources needed for them. This may support the mutual adaptation of refugees with society.

4. The misinformation that constitutes material for bad propaganda circulating in the community about refugees should be extracted, and the public should be given the correct information in widely used communication channels. Correct informative documents should be issued to public by public corporations and non-profit organizations working on refugees. It should also be made sure by the organizations concerned that the benefits of refugees to 
society are also emphasized. This may reduce the exclusionary behavior and maltreatment from society.

5. Public employees should be informed about the legislation and rights of refugees. This may reduce the refugees' rights losses due to differences between theory and practice. Thus, the social adaptation targeted by the relevant law can be achieved more rapidly and more effectively.

\section{Kaynakça / References}

Akdeniz, E. (2014). Suriye savaşının gölgesinde mülteci iş̧̧iler. İstanbul: Evrensel Basım Yayın.

Bahadır, H. ve Uçku, R. (2016). İzmir'in bir mahallesinde yaşayan 6-17 yaş arasındaki Suriyeli çocukların çalışma durumları ve çalışma durumlarını etkileyen etmenler. Dokuz Eylül Üniversitesi Tıp Fakültesi Dergisi, 30 (3), 117-124.

Birleşmiş Milletler Mülteciler Yüksek Komiserliği (19.4.2019). https://data2.unhcr.org/en/situations/syria/location. Adresinden 21 Nisan 2019 tarihinde erişildi.

Castells, S. ve M. J. Miller. (2008). Göçler çă̆ı modern dünyada uluslararası göç hareketleri. İstanbul: Bilgi Üniversitesi Yayınları.

Coşkun, E. ve Yılmaz, Ç. (2018). Sığınmacıların toplumsal uyum sorunlar1 ve sosyal hizmetlere erişimi: Düzce uydu kent örneği. Sosyal Siyaset Konferansları Dergisi, 75, 269-305.

Çağlayan, S. (2006). Göç kuramları, göç ve göçmen ilişkisi. Muğla Üniversitesi Sosyal Bilimler Enstitüsü Dergisi, 17, 67-91.

Çetin, İ. (2016). Suriyeli mültecilerin işgücüne katılımları ve entegrasyon: Adana-Mersin örneği. Gaziantep Üniversitesi Sosyal Bilimler Dergisi, 15(4), 1001-1016. DOI: 10.21547/jss.265320.

Duğan, Ö. ve Gürbüz, S. (2018). Suriyeli sığınmacıların sosyal entegrasyonuna yönelik bir araştırma. Electronic Turkish Studies, 13(26), 529-546. DOI: 10.7827/TurkishStudies.14625.

Esin, M. N., Ardıç, A., Nar, Ş., Yıldırım, B. ve Sunal, N. (2014). İstanbul'un bir bölgesinde yaşayan Suriyeli göçmenlerin yaşam koşulları. 17.Ulusal halk sağlı̆̆ı kongre kitabı içinde (s. 425-426). Edirne, Türkiye. ISBN: 978-605-84926-2-2. 
Karasu, M. A. (2016). Şanlıurfa'da yaşayan Suriyelï sığınmacıların kentle uyum sorunu. Süleyman Demirel Üniversitesi İktisadi ve İdari Bilimler Fakültesi Dergisi, 21(3), 995-1014.

Karasu, M. A. (2018). Suç korkusu, göç ve Suriyeli sığınmacılar: Şanlıurfa örneği. Uluslararası Yönetim Akademisi Dergisi, 1(3), 332-347.

Küçükşen, K. (2017). Suriyeli sığınmacı kadınlarda sosyal dışlanma algısı üzerine nitel bir çalışma. İnsan ve Toplum Bilimleri Araştırmaları Dergisi, 6(5), 2399-2413.

Mawani, F. N. (2014). Social determinants of refugee mental health. In L. Simich, \& L. Andermann (Ed.). Refuge and Resilience Promoting Resilience and Mental Health among Resettled Refugees and Forced Migrants. (pp. 27-50). USA: Springer Science+Business Media.

Özen, H. ve Cerit, C. (2018). Savaş nedeniyle Türkiye'ye göç ederek insani yardım kuruluşunda çalışan Suriyeli mültecilerde travma sonrası stres bozukluğu ve ilişkili etmenler. Kocaeli Üniversitesi Sağlık Bilimleri Dergisi, 4 (3), 70-73.

Resmi Gazete. (11.04.2013). Yabancilar ve Uluslararası Koruma Kanunu. 17 Mayıs 2019 tarihinde http://www.resmigazete.gov.tr/eskiler/2013/04/20130411-2.htm adresinden erişildi.

Sluzki, C. E. (1979). Migration and family conflict. 21 Nisan 2019 tarihinde https://sluzki.com/publications/articles/44/migration-andfamily-conflict adresinden erişildi.

T.C. İçişleri Bakanlığı Göç İdaresi Genel Müdürlüğü (2. 2. 2015). Geçici korumanın unsurları. 15 Mayı 2019 tarihinde http://www.goc.gov.tr/icerik3/gecici-korumanin-unsurlari_409_558_1095 adresinden erişildi.

Taştan, C., Haklı, S. H. ve Osmanoğlu, E. (2017). Suriyeli sığınmacılara dair tehdit algısı: Önyargılar ve gerçekler. (Rapor No. 9). Ankara: Polis Akademisi Yayınları.

Ünal, S. (2014). Türkiye'nin beklenmedik konukları: “Öteki” bağlamında yabancı göçmen ve mülteci deneyimi. Zeitschrift für die Welt der Türken, 6(3), 65-89.

Valtonen, K. (2008). Social work and migration immigrant and refugee settlement and integration. England: Ashgate Publishing Limited. 
Yıldırımalp, S., İslamoğlu, E. ve İyem, C. (2017). Suriyeli sığınmacıların toplumsal kabul ve uyum sürecine ilişkin bir araştırma. Bilgi, 19(2), 107-126.

\section{Kaynakça Bilgisi / Citation Information}

Güneş-Aslan, G. ve Güngör, F. (2019). Suriyeli sığınmacıların Türkiye'ye göç sonrası yaşadığı sorunlar: İstanbul örneği. OPUS-Uluslararası Toplum Araştırmaları Dergisi, 11(18), 1602-1632. DOI: 10.26466/opus.558512 